\title{
MANAJEMEN PENGEMBANGAN GURU
}

\author{
Ipong Dekawati \\ Universitas Pendidikan Indonesia (e-mail: mustofa.sulaeman@yahoo.com;
}

HP: 08122106393)

\begin{abstract}
The Teacher Development Management. The research is aimed at analyzing the effects of further study, profession training, participation in scientific forums, further study and profession training as an aggregate, further study and participation in scientific forums as an aggregate, and profession training and participation in scientific forums as an aggregate on teachers' performance, and analyzing the effectiveness of the teacher development management through those three activities. This study was a descriptive and explanatory survey. The results show all the three activities affect the teachers' performance. This indicates that the teacher development program through those three activities is effective.
\end{abstract}

Keywords: further study, profession training, scientific forums, performance

\section{PENDAHULUAN}

Salah satu alternatif pencapaian harapan masyarakat Indonesia sejahtera adalah berkembangnya dunia usaha dan dunia industri yang dapat menyerap banyak tenaga kerja. Peluang kerja dunia usaha dan dunia industri, khususnya untuk tenaga pelaksana sampai tingkat pengawas, secara teoretik mudah didapatkan oleh pencari kerja tamatan sekolah menengah kejuruan (SMK). Sejalan dengan pendapat Supriadi (2002:17), bahwa pendidikan kejuruan bertujuan untukmenghasilkan manusia yang produktif, yakni manusia kerja, bukan manusia beban bagi keluarga.

Malik Fajar (Supriadi, 2002:iii) juga memiliki pandangan yang sama dengan mengatakan bahwa:

"Pendidikan kejuruan merupakan investasi yang mahal namun strategik dalam menghasilkan manusia Indonesia yang terampil dan berkeahlian dalam bidang- bidangnya sesuai dengan kebutuhan masyarakat dan bangsa khususnya dunia usaha dan industri."

Pada kenyataannya, masih dijumpai keluhan atas lulusan SMK yang kurang terampil sehingga tidak siap untuk bersaing meraih pekerjaan. Hal itu disebabkan antara lain oleh ketidaksiapan lulusan untuk melaksanakan pekerjaan dan kesenjangan vokasional antara latar belakang keterampilan angkatan kerja lulusan SMK dengan kompetensi yang dibutuhkan oleh dunia usaha dan dunia industri. Ketidaksiapan lulusan SMK tersebut diperkuat oleh ungkapan Sukmadinata (2003:1) bahwa dalam bidang pendidikan kejuruan, salah satu hal yang masih menjadi keprihatinan adalah kemampuan SMK untuk menghasilkan lulusan yang siap kerja.

Kondisi demikian menuntut dilakukannya upaya-upaya yang lebih serius untuk menyelaraskan pendidikan di 
SMK dengan tuntutan dunia kerja. Kesenjangan antara kompetensi yang dimiliki lulusan SMK dengan kompetensi yang dipersyaratkan oleh pengguna lulusannya dapat dijembatani dengan solusi alternatif berupa pengembangan guru. Upaya tersebut dapat dilakukan melalui pengembangan guru sesuai dengan Peraturan Menteri Pendidikan Nasional Nomor 16 Tahun 2007 tentang Standarisasi Akademik dan Kompetensi Guru. Undang-Undang Republik Indonesia Nomor 20 Tahun 2003 tentang Sistem Pendidikan Nasional; UndangUndang Republik Indonesia Nomor 14 Tahun 2005 tentang Guru dan Dosen; dan Peraturan Pemerintah Republik Indonesia Nomor 19 Tahun 2005 tentang Standar Nasional Pendidikan menyatakan bahwa guru adalah pendidik profesional. Untuk itu, guru dipersyaratkan memiliki kualifikasi akademik minimal sarjana atau diploma IV yang relevan, dan menguasai kompetensi sebagai agen pembelajaran. Sementara itu, masih banyak guru yang belum berpendidikan sarjana atau diploma IV. Di Jawa Barat guru SMK yang berkualifikasi minimal S-1D-4 hanya 82\% (Rencana Strategis Depdiknas 2010-2014, 2009:31). Jumlah guru SMK yang berkualifikasi minimal S-1/D-4 tersebut belum dilihat dari faktor relevansinya. Karena kenyataan menunjukkan masih terdapat guru SMK yang latar belakang kualifikasi akademiknya tidak linier dengan mata pelajaran yang diampu.

Dalam menyikapi urgensi tuntutan dan kebutuhan guru SMK yang kompeten, pemerintah pusat maupun daerah telah menempuh beragam upaya. Upaya tersebut dilaksanakan melalui pro- gram pengembangan guru berupa pendidikan lanjut, sertifikasi guru, pelatihan-pelatihan, seminar, lokakarya, studi banding, dan jenis-jenis program lainnya. Khusus di Kabupaten Majalengka, pengembangan guru yang sudah berlangsung bersifat pengembangan guru yang dilaksanakan pemerintah dan pengembangan guru secara individu. Pengembangan yang bersifat individu atau pengembangan diri, biayanya ditanggung secara swadana dari guru yang bersangkutan. Oleh karena itu, guru yang mengikuti pendidikan lanjut mendapatkan izin dari atasan dengan catatan tidak meninggalkan tugas sehingga dalam mengikuti pendidikan lanjut mencari lembaga pendidikan yang lokasinya tidak jauh dari tempat kerja agar tidak meninggalkan tugas mengajar. Sementara itu, di Kabupaten Majalengka sendiri perguruan tinggi masih terbatas.

Keinginan guru SMK untuk mengikuti pendidikan lanjut cukup tinggi gunamemenuhi tuntutan peraturan tentang kompetensi akademik guru. Oleh karena itu, muncul masalah guru melanjutkan pendidikan tidak sesuai dengan latar belakang pendidikan sebelumnya. Pada observasi awal, penulis menemukan 937 orang guru SMK yang digunakan sebagai populasi. Kebutuhan idealnya sebanyak 1.319 orang. Selain jumlahnya masih kurang, guru SMK yang ada masih terdapat 103 orang $(7,91 \%)$ belum S1, 120 orang $(9,22 \%)$ kurang relevan antara latar belakang pendidikan dengan mata pelajaran yang diampu. Kemudian, dapat diidentifikasi bahwa (1) jumlah guru belum memenuhi kebutuhan riil SMK; (2) masih ditemukan guru yang mismacth antara la- 
tar belakang pendidikan dengan mata pelajaran yang mereka ampu; dan (3) masih ditemukan adanya guru SMK yang belum memiliki kompetensi akademik, dalam arti baru berijazah Diploma III.

Melihat semangat pengembangan diri guru yang disebabkan oleh tuntutan peraturan bahwa guru harus sarjana atau diploma IV, tuntutan sosial, dunia usaha dan dunia industri serta belum terencananya secara matang pengembangan guru sebagaimana diutarakan dimuka, maka gagasan utama penelitian ini ingin menganalisis secara faktual pengaruh pengembangan diri melalui pendidikan lanjut, pelatihan profesi dan kesertaan pada forum ilmiah yang pada gilirannya terformulasikan strategi pengembangan guru yang diharapkan lebih berhasilguna.

Kinerja guru SMK merupakan salah satu penentu kualitas dan kompetensi lulusan yang responsif terhadap perkembangan dan tuntutan dunia usaha dan industri. Kinerja guru itu sendiri dipengaruhi banyak faktor, seperti: kemampuan, keterampilan, sikap, motivasi, iklim kerja, pendidikan, pelatihan, kepemimpinan, dan lain-lain. Penelitian ini dibatasi hanya membahas faktor kurang optimalnya kinerja guru secara garis besar disebabkan oleh latar belakang pendidikan dan kompetensi guru yang tidak relevan dengan mata pelajaran yang diampu. Menurut Sapaat (2004) yang dikutip Suhendro (http://duniaguru.com, diakses 2009), dikatakan bahwa guru yang tidak menguasai bahan ajar, tidak menguasai landasan-landasan kependidikan, tidak menguasai psikologi belajar siswa dan kompetensi lainnya sudah tidak dapat diandalkan lagi da- lam konteks pelaksanaan tugas dan tanggung jawabnya sebagai guru yang profesional.

Guru yang profesional memiliki kriteria kompetensi yang sudah ditetapkan. Kriteria tersebut dapat mengantisipasi dan menjawab kompetensi yang harus dimiliki oleh para lulusan, yaitu lulusan yang memiliki kompetensi sesuai kebutuhan dunia usaha dan dunia industri pada zamannya. Apabila guru tidak menguasai bahan ajar, konsekuensinya ilmu yang ditransfer kepada peserta didik tidak sesuai harapan. Jika tidak menguasai landasan kependidikan, proses transfer ilmu kurang optimal, dan jika guru tidak menguasai psikologi belajar, maka penekanan (stressing) dalam proses pembelajaran dan pemahaman terhadap peserta didik kurang pas.

Menggarisbawahi kata profesional menurut Engkoswara (2006) pada Seminar Pendidikan bagi Anggota ISPI untuk Meningkatkan Mutu Pendidikan di Sumedang mengatakan bahwa profesional adalah suatu paham bahwa suatu pekerjaan seyogyanya sesuai dengan ilmu dan teknologi yang dibutuhkannya sesuai tingkat pendidikan yang diperlukan. Menurut Glenn Langford (Yamin (2006:31), kriteria profesi mencakup : (1) upah; (2) memiliki pengetahuan dan keterampilan; (3) memiliki rasa tanggung jawab dan tujuan; (4) mengutamakan layanan; (5) memiliki kesatuan; dan (6) mendapat pengakuan dari orang lain atas pekerjaan yang digelutinya. Sementara itu, Moore (Yamin, 2006:31) mengidentifikasikan profesi memiliki ciri-ciri: (1) seseorang profesional menggunakan waktu penuh untuk menjalankan pekerjaannya; (2) ia terikat oleh panggilan 
hidup, dan dalam hal ini memperlakukan pekerjaannya sebagai seperangkat norma kepatuhan dan perilaku; (3) ia anggota organisasi profesional yang formal; (4) ia menguasai pengetahuan yang berguna dan keterampilan atas dasar latihan spesialisasi atau pendidikan yang sangat khusus; (5) ia terikat dengan syarat-syarat kompetensi, kesadaran prestasi, dan pengabdian; dan (6) ia memperoleh otomi berdasarkan spesialisasi teknis yang tinggi sekali.

Menurut Yamin (2006:20), profesi menimbulkan makna bahwa profesi yang disandang oleh tenaga kependidikan atau guru adalah suatu pekerjaan yang membutuhan pengetahuan, keterampilan, kemampuan, keahlian, dan ketelatenan untuk menciptakan anak didik memilki perilaku sesuai yang diharapkan. Guru memiliki pendidikan khusus, memiliki kemampuan pengetahuan, memiliki kemampuan keahlian dan ketelatenan, memiliki kewenangan yang diakui klien, memiliki norma-norma etis, seperti kode etik guru, dan memiliki solidaritas kelompok profesi. Guru juga terikat dengan syarat-syarat kompetensi, kesadaran prestasi dan pengabdian, serta guru menerima upah, maka jelaslah guru merupakan profesi. Oleh karena itu, guru merupakan tenaga profesional. Karena keprofesionalannya itu, guru harus selalu mengembangkan diri. Dalam kaitan pengembangan diri, guru sebagaimana disarankan Mariani dan Doriza (Jurnal Pendidikan dan Kebudayaan Volume 15 Edisi Khusus II tahun 2009) bahwa untuk sekurang-kurangnya mencapai skor minimum tersertifikasi, beberapa hal dapat dilakukan, yaitu: (1) melanjutkan studi ke jenjang S2 berdasarkan linieritas jenjang S1 atau melanjutkan jenjang studi berdasarkan mata pelajaran yang diampu; (2) ikut serta dalam kegaiatan pelatihan dan forum ilmiah tidak hanya di tingkat lokal atau kabupaten, namun di tingkat nasional, bahkan internasional dengan rajin membuka Website LPTK; dan 3) selalu mengikuti kegiatan berdasarkan cara gurubelajar, misalnya: membiasakan melakukan penelitian tindakan kelas, kegiatan MGMPMGMK, kegiatan konsultasi, dan lain-lain.

\section{PENGEMBANGAN DAN KINERJA GURU}

Pengembangan guru merupakan proses penting yang dirancang dalam suatu organisasi untuk mempertahankan dan meningkatkan kualitas guru dalam rangka mencapai tujuan pendidikan. Guru yang perlu dikembangkan adalah yang dipertimbangkan merefleksikan kesenjangan antara kondisi yang ada dengan kondisi yang diharapkan. Kesenjangan itu dicerminkan oleh melemahnya sebagian atau keseluruhan budaya organisasi, seperti dikemukakan Castetter (1996:238):

"They are considered to reflect a gap between existing and desired condition, whether the gap is viewed as a deficiency or part of the organization's culture that stresses continual growth and development for all system members."

Selain pengembangan guru dapat dilakukan oleh institusi untuk kepentingan institusi itu sendiri, terutama berkaitan dengan mutu output, kinerja, motivasi kerja dan semangat kerja, dapat pula dilakukan oleh guru itu sendiri dalam bentukpengembangan diri. Pengem- 
bangan guru melalui pendidikan lanjut perlu mempertimbangkan fungsi guru, kebutuhan dan kemampuan guru, seperti disampaikan oleh McNergney dan Carrier (1981:18):

"It is concerned necessarily with the tasks and behaviors of teaching and learning, butnever in isolation from the people who function as teachers. Therefore, we see it as personalized in the sense that the environments created by teacher educators must be congruent with the teachers' needs and abilities."

Pendidikan lanjut bagi guru, tidak efisien bila hanya mempertimbangkan karakteristik guru. Pengembangan guru juga diasumsikan saling ketergantungan yang interaktif dengan orang-orang, perilaku, tugas-tugas, dan lingkungan. Oleh karena itu, harus terakomodir secara sistematis ketika proses dan prosedur pengembangan guru diinvestigasi, dirancang, dan dilaksanakan, sebagaimana disampaikan McNergney dan Carrier (1981:18):

"It is not sufficient to consider only teacherchracteristic; teacherdevelopment isalso interactive in that persons, behaviors, tasks, and environments are assumed to be interdependent. Theymust thereforebeaccommodated systematically when teacher developmentprocessesand procedures are designated, practiced, or investigated."

Secara filosofis, pendidikan guru dapat mengembangkan guru untuk tumbuh menjadi seorang yang profesional. Seperti dikemukakan oleh McNergney dan Carrier (1981:1):

"Thepurpose of teacher education should be to encourage the growth of teachers as persons and asprofessionals. Teachers who are growing are becoming more open, more humane, more skillful, more complex, more complete pedagogues and human beings."

Hal ini mengandung makna bahwa tujuan pendidikan guru harus dapat mendorong pertumbuhan guru sebagai manusia yang profesional. Guru yang berkembang menjadi lebih terbuka, lebih humanis, lebih terampil, lebih kompleks, lebih memiliki pedagogis yang lengkap atau mumpuni dan lebih manusiawi.

Secara teoretis, pengembangan dapat meningkatkan kemampuan pegawai/guru dalam melaksanakan pekerjaannya. Hal ini dapat dimaknai bahwa materi pengembangan guru SMK harus relevan dengan mata pelajaran yang diampu seperti disampaikan Hasibuan (2009:69) bahwa pengembangan adalah usaha untuk meningkatkan kemampuan teknis, teoretis, konseptual, dan moral karyawan sesuai dengan kebutuhan pekerjaan/jabatan melalui pendidikan dan latihan. Selanjutnya, didukung oleh pendapat Flippo (1984:215) yang menyatakan bahwa pengembangan meliputi baikpelatihan untuk meningkatkan keterampilan dalam melaksanakan pekerjaan tertentu maupun pendidikan untuk meningkatkan pengetahuan umum dan pemahaman atas keseluruhan lingkungan.

Pelatihan meliputi rencana programprogram dirancang untuk meningkatkan tampilan individu, kelompok dan atau pada tingkat organisasi. Peningkatan tampilan, mengarah pada hal-hal yang terukur seperti perubahan pada pengetahuan, keterampilan, kepribadi- 
an dan atau perilaku sosial, sebagaimana disampaikan Cascio (1993:245):

"Training consists of planned programs designed to improve performance at the individual, group, and/or organizational levels. Improved performance, in turn, implies that there have been measurable changes in knowledge, skills, attitudes, and/or social behavior."

Pelatihan juga merupakan akuisisi (memperoleh) pengetahuan yang memungkinkan pegawai mencapai tampilan kerja sesuai standar. Pelatihan dapat didefinisikan sebagai suatu pengalaman, suatu disiplin atau suatu aturan yang menyebabkan orang-orang mencapai hal baru, perilaku yang diharapkan pada masa yang akan datang, sebagaimana dikemukakan Laird (1985: 11):

"Training is the acquisition of the knowledge which permits employees to perform standard. Thus training may be defined as an experience, a dicipline, or a regimen which causes people to acquire new, predetermined behaviors."

Tjiptono dan Anastasia (2003:223) menyatakan:

"Tujuan pelatihan untuk meningkatkan pengetahuan, keterampilan, dan sikap karyawan serta meningkatkan kualitas dan produktivitas organisasi secara keseluruhan. Dengan kata lain, tujuan pelatihan adalah meningkatkan kinerja dan pada gilirannya akan meningkatkan daya saing."

Untuk menjadi guru profesional, diperlukan pembelajaran secara kesinambungan agar tidak terjadi stagnasi keilmuan dan informasi. Salah satu pengembangan guru dapat dilakukan melalui forum ilmiah, seperti kesertaan pada konferensi dan konvensi sehingga membawa pulang ide-ide yang mereka akan mengujicobakannya, atau paling tidak dapat berbagi dengan kawan kerjanya. Dalam kaitan ini, Laird (1985:76) menyampaikan:

"Professional coferences and conventions provide another source of learning to meet micro training needs. They are seldom structured as behaviorally oriented learning system"

"Hopefully, people who attend conferences and conventions will bring back ideas which they will try out, or at very least share with their peers" (Laird (1985:76).

Pengembangan pegawai dalam hal ini guru juga dapat dilakukan melalui metode pertemuan ilmiah atau keikutsertaan pada forum ilmiah, seperti seminar. Menurut Sastrohadiwiryo (2002: 217), seminar juga dapat dikatakan sebagai suatu pertemuan ilmiah untuk mengemukakan serta mempertimbangkan berbagai pendapat atau keyakinan mengenai suatu masalah.

Lokakarya juga merupakan salah satu kegiatan pengembangan pegawai. Seperti dikemukakan Sastrohadiwiyo (2002:217) bahwa lokakarya sering digunakan karena ada beberapa kebaikannya, antara lain memberikan kesempatan untuk berfungsi spesifik, seperti profesional dan kejuruan, serta memberikan cara menetapkan tujuan yang ingin dicapai oleh kelompok dan metode kerja.

Selain seminar dan lokakarya, metode lain yang termasuk pada pengembangan guru yaitu simposium. Simposium menurut Sastrohadiwiryo (2002: 217) adalah serangkaian pembicaraan yang diberikan oleh beberapa ahli dalam bidangnya masing-masing yang 
berfungsi sebagai pemrasaran dengan keahlian masing-masing yang berbeda tentang berbagai aspek dari sesuatu masalah.

Selanjutnya, mengenai kinerja atau tampilan kerja dalam bahasa Inggris dikenal job performance, yaitu catatan tentang hasil-hasil yang diperoleh dari fungsi pekerjaan tertentu atau kegiatan tertentu selama kurunwaktu tertentu sebagaimana disampaikan Bernardin dan Russel (1993:378), "Performance is defined as the record of outcomes produced on a specified job function or activity during a specified time period."

Sementara itu, Fattah (2008:19) mendefinisikan kinerja sebagai ungkapan kemampuan yang didasari oleh pengetahuan, sikap, dan keterampilan serta motivasi dalam menghasilkan sesuatu. Kinerja dapat menjadi tolok ukur pencapaian tujuan organisasi dan prestasi kerja pegawai yang berkaitan dengan imbalan jasa. Kinerja guru merupakan prestasi yang dapat dicapai seorang guru berdasarkan kriteria dan alat ukur tertentu. Parameter yang paling umum digunakan menurut Drucker (1997:23) adalah "efektivitas, efisiensi, dan produktivitas". Hal ini sejalan dengan pandangan Sutermeister (1976:11), bahwa job performance (kinerja) sebagai human contributions to productivity atau kinerja sebagai kontribusi manusia pada produktivitas.

Berkaitan dengan penilaian kinerja, Dharma (2009:101) menyatakan bahwa penilaian kinerja didasarkan pada pemahaman pengetahuan, keahlian, kepiawaian dan perilaku yang diperlukan untuk melaksanakan suatu pekerjaan dengan baik dan analisis tentang atribut perilaku seseorang sesuai kriteria yang ditentukan untuk masing-masing pekerjaan.

Kinerja atau unjuk kerja merupakan kuantitas layanan dan produk sekolah bagi siswa, pendidik, dan pihak lain dan kualitas dari setiap keluaran (output). Contoh, indikator outcome adalah prestasi akademik, kepuasan kerja, sikap guru dan siswa, persentase siswa dropout, tingkat kemangkiran guru, komitmen pegawai terhadap organisasi dan persepsi masyarakat terhadap efektivitas sekolah, sebagaimana dikemukakan Hoy dan Miskel (2001:295-296):

"Performance outcomes constitute the quantity of the school's services and products for students, educators, and other constituents and the quality of each output. These are the effects of the organization. Examples of outcome indicators are academic achievement job satisfaction, teacher and student attitudes, student dropout rates, teacher absenteeism levels, employee commitment to the organization, and society's perceptions of school effectiveness."

Efektivitas sekolah sebagai asumsi dasar dalam pembahasan ini adalah bahwa efektivitas organisasi merupakan konsep yang bersegi banyak. Artinya, model-model harus memasukkan kriteria ganda. Tidak ada kriteria akhir seperti prestasi siswa atau kinerja keseluruhan yang dapat mewakili seluruh cakupan efektivitas sekolah, seperti yang disampaikanHoydan Miskel (2001:295):

"A basic assumption throughout this discussion has been that organizaional effectiveness is a many faceted concept - that is, models must include multiple criteria. No single ultimate criterion such as student achievement or overall performance can capture the complex nature of school effectiveness." 


\section{METODE}

Penelitian ini menggunakan pendekatan descriptive survey dan explanatory survey, dilaksanakan pada 35 SMK negeri dan swasta di Kabupaten Majalengka, Propinsi Jawa Barat. Populasinya adalah seluruh guru SMK yang berjumlah 937 orang. Dengan asumsi bahwa dilihat dari kinerjanya, semua guru mendapat kesempatan sama untuk dijadikan sampel. Oleh karena itu, pengambilan sampel digunakan metode simple random sampling. Dari 937 orang guru, diambil 100 orang sebagai sampel. Jumlah sampel tersebut telah memenuhi syarat dengan mengacu pada pendapat Roscoe (Sugiyono, 2010:102-103), yaitu jumlah sampel lebih dari sepuluh kali lipat variabel yang diteliti.

Dalam penelitian ini, instrumen yang digunakan untuk mengumpulkan data adalah angket/kuesioner. Angket disusun berskala pengukuran ordinal mengingat angket yang disebarkan menggunakan Skala Likert dengan kisaran secara kontinus $1-5$.

\section{HASIL}

Setelah melalui pengujian dan analisis, secara umum hasil penelitian dapat dilihat sebagaimana paparan berikut.

Pendidikan Lanjut $\left(X_{1}\right)$ berpengaruh terhadap Kinerja Guru SMK (Y), berdasarkan pengujian koefisien jalur dari $\mathrm{X}_{1}$ terhadap $Y$ secara statistik bermakna. Besarnya pengaruh pendidikan lanjut terhadap kinerja guru $\left(\mathrm{X}_{1}\right.$ terhadap $\left.\mathrm{Y}\right)$ adalah sebesar $0,0506+0,0195=0,0701$ (7,01\%). Artinya, kinerja guru ditentukan oleh pendidikan lanjut sebesar 7,01\%.

Pelatihan Profesi $\left(\mathrm{X}_{2}\right)$ berpengaruh terhadap Kinerja Guru SMK (Y), berda- sarkan pengujian koefisien jalur dari $\mathrm{X}_{2}$ terhadap $Y$ secara statistik bermakna. Besarnya pengaruh pelatihan profesi terhadap kinerja guru ( $\mathrm{X}_{2}$ terhadap $\left.\mathrm{Y}\right)$ adalah sebesar 0,3561 +0,0248=0,3809 $(38,09 \%)$. Artinya, kinerja guru ditentukanoleh pelatihan profesisebesar38,09\%.

Kesertaan pada Forum Ilmiah $\left(\mathrm{X}_{3}\right)$ berpengaruh terhadap Kinerja Guru SMK (Y) berdasarkan pengujian koefisien jalur dari $\mathrm{X}_{3}$ terhadap $\mathrm{Y}$ secara statistik bermakna. Besarnya pengaruh keikutsertaan dalam forum ilmiah terhadap kinerja guru $\left(\mathrm{X}_{3}\right.$ terhadap $\left.\mathrm{Y}\right)$ adalah $0,1410+0,0243=0,1653(16,53 \%)$. Artinya, kinerja guru ditentukan oleh keikutsertaan guru dalam forum ilmiah sebesar $16,53 \%$.

Pendidikan Lanjut $\left(\mathrm{X}_{1}\right)$ dan Pelatihan Profesi $\left(X_{2}\right)$ secara bersama-sama berpengaruh terhadap Kinerja Guru SMK $(Y)$, berdasarkan pengujian koefisien jalur dari $\mathrm{X}_{1}$ dan $\mathrm{X}_{2}$ terhadap $\mathrm{Y}$ secara statistik bermakna, yakni: 0.3842 atau 38,42\%.

Pendidikan Lanjut $\left(\mathrm{X}_{1}\right)$ dan Kesertaan pada Forum Ilmiah $\left(\mathrm{X}_{3}\right)$ secara bersama-samaberpengaruh terhadap Kinerja Guru SMK (Y), berdasarkan pengujian koefisien jalur dari $X_{1}$ dan $X_{3}$ terhadap $Y$ secara statistik bermakna, yakni: 0.2516 atau 25,16\%.

Pelatihan Profesi $\left(\mathrm{X}_{2}\right)$ dan Kesertaan pada Forum Ilmiah $\left(X_{3}\right)$ secara bersamasama berpengaruh terhadap Kinerja Guru SMK (Y), berdasarkan pengujian koefisien jalur dari $\mathrm{X}_{2}$ dan $\mathrm{X}_{3}$ terhadap $\mathrm{Y}$ secara statistik bermakna, yakni: 0.4865 atau $48,65 \%$.

Pendidikan Lanjut $\left(\mathrm{X}_{1}\right)$, Pelatihan Profesi $\left(X_{2}\right)$ dan Kesertaan pada Forum Ilmiah $\left(\mathrm{X}_{3}\right)$ secara bersama-sama terha- 
dap Kinerja Guru SMK (Y). Berdasarkan pengujian koefisien jalur dari $X_{1}, X_{2}$ dan $X_{3}$ bersama-sama terhadap $Y$ secara statistik bermakna, yakni: 0,6162.

Besarnya variabel residu, yaitu variabel yang mempengaruhi variabel endogenus di luar variabel eksogenus. Besarnya pengaruh total $X_{1}, X_{2}$ dan $X_{3}$ terhadap $Y$ (pengaruh $X_{1}, X_{2}$ dan $X_{3}$ terhadap $Y$ secara bersama-sama) sebesar 0,6162 . Hal ini menunjukkan bahwa secara bersama-sama Pendidikan Lanjut, Pelatihan Profesi, dan Kesertaan pada
Forum Ilmiah memberikan pengaruh terhadap kinerja guru sebesar $61,62 \%$. Sisanya, ditentukan oleh variabel lain yang tidak diteliti, sebagaimana ditunjukan oleh variabel residu $(\varepsilon)$, yaitu 0,3838 . Besarnya pengaruh variabel residu $\varepsilon$ terhadap $\mathrm{Y}=0,3838(=38,38 \%)$.

Berdasarkan hasil penelitian di atas, paradigma empirik pengaruh pendidikan lanjut, pelatihan profesi dan kesertaan pada forum ilmiah terhadap kinerja guru dapat digambarkan sebagai berikut.

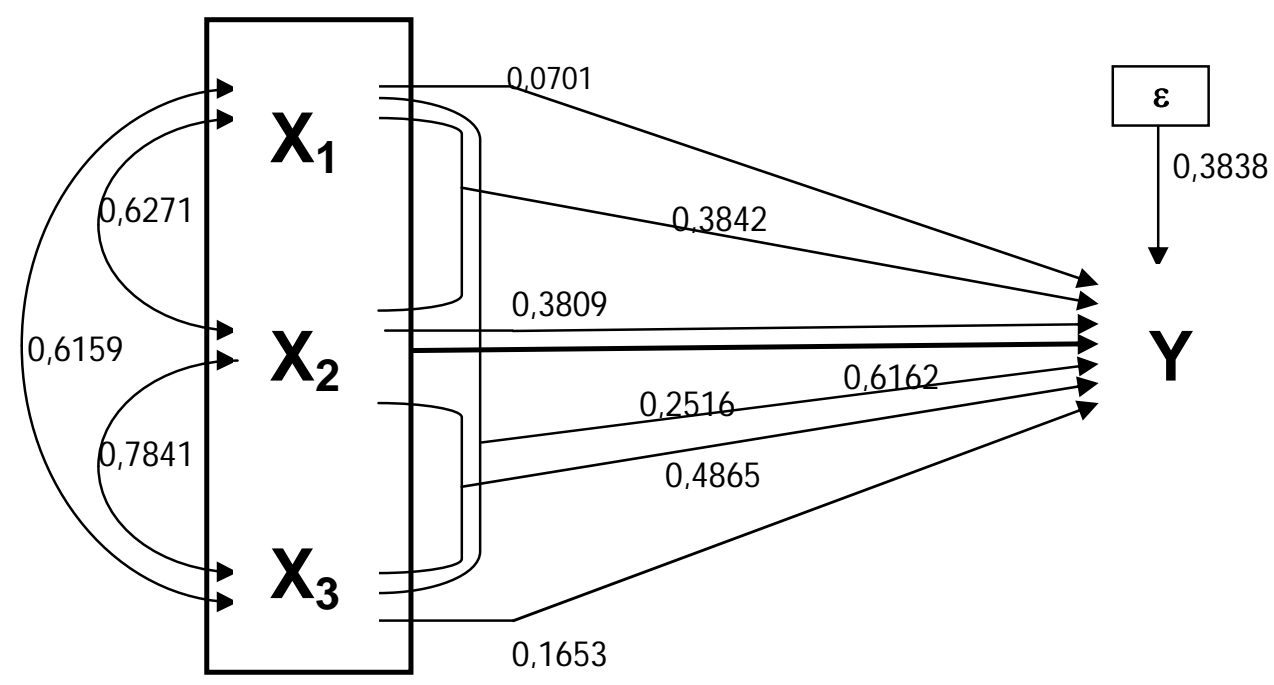

\section{PEMBAHASAN}

Setiap upaya pembelajaran, baik formal, nonformal ataupun informal selalu ada tujuan dan sasaran yang ingin dicapai. Demikian pula dengan pendidikan lanjut yang diikuti oleh guru sebagai agen pembelajaran. Berbagai tujuan yang ingin dicapai oleh peserta didik dimaksud, mulai yang murni merupakan keinginan yang tulus dan hakiki (drive) dari dalam kalbunya. Kelompok ini da- pat dikategorikan sebagai insan pembelajar yang murni menuntut ilmu. Tidak sedikit pula yang karena mengejar prestise.

Di lain pihak, lembaga manapun selalu berupaya untuk dapat memperbaiki kinerja pegawai. Apalagi pada satuan pendidikan yang seharusnya menjadi nahkoda kemajuan bangsa. Satuan pendidikan merupakan unit terkecil dalam ranah pendidikan yang dapat di- 
jadikan parameter kemajuan bangsa. Misalnya, melalui tolok ukur indeks pembangunan manusia yang salah satu indikatornya adalah pendidikan. Oleh karena itu, persaingan konstruktif antarsatuan pendidikan dapat menjadi faktor pendukung kemajuan pendidikan secara makro. Salah satu upayanya melalui peningkatan kinerja.

Guna mencapai kinerja yang diharapkan, perlu ada pengembangan guru, baik pengembangan diri secara indivi$\mathrm{du}$ atau pengembangan terstruktur sesuai kebutuhan institusi. Dengan dilaksanakannya pengembangan, besar harapan kemampuan dan keterampilan guru meningkat. Selain itu, pengembangan guru juga berkaitan dengan motivasi kerja yang dapat memperbaiki kinerja. Pengembangan guru yang populer sekarang ini berupa pendidikan lanjut karena tuntutan regulasi yang harus terpenuhinyakualifikasiakademik guru, yaitu strata I. hanya saja, tidak semua wilayah dapat melaksanakan pendidikan lanjut sesuai dengan latar belakang pendidikan sebelumnya atau dengan mata pelajaran yang diampu. Karena tidak di setiap wilayah di Jawa Barat ini tersedia perguruan tinggi yang lengkap program studinya sehingga masih banyak guru yang pendidikan lanjutnya tidak linier. Linieritas yaitu kecocokan antara latar belakang pendidikan guru dengan mata pelajaran yang diampu. Pendidikan lanjut yang linier yaitu yang selaras dengan latar belakang pendidikan sebelumnya. Apabila pengembangan guru sesuai dengan pendidikan sebelumnya peningkatan kinerjanya akan signifikan. Sekalipun linieritasnya kurang optimal, ternyata pendidikan lanjut ma- sih memiliki pengaruh yang signifikan terhadap kinerja guru.

Setelah dianalisis, variabel pendidikan lanjut berpengaruh terhadap kinerja guru secara langsung sebesar 0,0506. Pengaruh tidak langsung sebesar 0,0195 . Sesuai dengan perhitungan menunjukkan bahwa kinerja guru SMK dipengaruhi oleh pendidikan lanjut sebesar 0,0701 . Pengaruh pendidikan lanjut terhadap kinerja guru masih dianggap belum optimal karena pendidikan lanjut yang selama ini terlaksana banyak yang tidak sesuai dengan latar belakang pendidikan sebelumnya atau tidak linier sehingga kurang berpengaruh langsung terhadap bidang studi yang diampu. Hal ini bisa terjadi karena kondisi di daerah seperti Majalengka, lembaga pendidikan lanjut yang tersedia dan dapat dijangkau dengan tidak meninggalkan tugas sangat terbatas. Oleh karena itu, kesertaan pada pendidikan lanjut menjadi tergiring pada lembaga yang tersedia sekalipun kurang relevan dengan bidang studi yang diampu.

Pelatihan profesi berpengaruh terhadap kinerja guru secara langsung sebesar 0,3561 . Pengaruh tidak langsung sebesar 0,0248. Sesuai dengan perhitungan menunjukkan bahwa kinerja guru SMK dipengaruhi oleh pelatihan profesi sebear 0,3809. Tujuan pelatihan guru untuk meningkatkan atau menyesuaikan keterampilannya dengan perubahan kurikulum yang berlaku, atau dengan perubahan yang terjadi di dunia usaha dan dunia industri, baik perubahan prosedural atau teknologi. Dengan demikian, guru SMK selalu dapat beradaptasi dengan kondisi yang ada sehingga ilmu 
atau keterampilan yang dimilikinya dapat ditransfer kepada siswa.

Kesertaan pada forum ilmiah berpengaruh terhadap kinerja guru secara langsung sebesar 0,1410. Pengaruh tidak langsung sebesar 0,0243. Sesuai dengan perhitungan menunjukkan bahwa kinerja guru SMK dipengaruhi oleh kesertaan pada forum ilmiah sebesar 0,1653. Kebermanfaatan kesertaan pada forum ilmiah belum optimal. Hal ini disebabkan kurang relevan antara kegiatan forum ilmiah yang diikuti dengan bidang studi yang diampu, terutama kesertaan pada forum ilmiah di luar MGMP.

Pengaruh pendidikan lanjut dan pelatihan profesi secara bersama-sama mencapai 0,3842. Pengaruh pendidikan lanjut dan kesertaan pada forum ilmiah secara bersama-sama mencapai 0,2516, Pengaruh pelatihan profesi dan kesertaan pada forum ilmiah secara bersamasama mencapai 0,4865. Itu semua menggambarkan bahwa kinerja guru SMK lebih tinggi kebermanfaatannya melalui pengembangan pelatihan profesidan kesertaan pada forum ilmiah. Karena terbukti kinerja lebih banyak dipengaruhi oleh kedua faktor tersebut hingga mencapai 0,3842 dan 0,4865.

Secara bersama-sama, ketiga faktor pendidikan lanjut, pelatihan profesi dan kesertaan pada forum ilmiah berpengaruh terhadap kinerja mengajar guru SMK di Kabupaten Majalengka sebesar 0,6162 . Sesuai dengan perhitungan menunjukkan bahwa kinerja guru SMK di Kabupaten Majalengka dipengaruhi oleh faktor-faktor lain di luar pendidikan lanjut, pelatihan profesi dan kesertaan pada forum ilmiah sebesar 0,3838.
Mengacu pada uraian di atas, dapat dianalisis bahwa pelaksanaan pengembangan guru SMK di Kabupaten Majalengka secara parsial maknanya belum efektif dikarenakan belum terformulasinya perencanaan yang matang atau manajemen pengembangan guru belum dikelola dengan baik. Pengembangan guru yang sudah berlangsung mayoritas bersifatpengembangan guru yang dilaksanakan secara individu. Keinginan guruSMKuntukmengikutipendidikan lanjut cukup tinggi guna memenuhi tuntutan peraturan yang berlaku tentang kompetensi akademik guru. Oleh karena itu, pendidikan lanjut yang diikuti kurangrelevan dengan latar belakang pendidikan sebelumnya serta mata pelajaran yang diampunya. Pengembangan guru SMK berlangsung kurang efektif.

Berdasaarkan pembahasan di atas, jika dianalisis secara menyeluruh dari tiga program pengembangan guru, yaitu pendidikan lanjut, pelatihan profesi dan kesertaan pada forum ilmiah tingkat, efektivitasnya termasuk kuat atau efektif. Dikatakan demikian karena pengaruh yang 0,6162 dibandingkan dengan kriteria interpretasi skor yang dikemukakan Sugiyono (2008:184) termasuk pada rentang interval koefisien 0,60 hingga 0,799 atau sama dengan kuat. Dengan demikian, tingkat efektivitas pengembangan guru secara menyeluruh pendidikan lanjut, pelatihan profesi dan kesertaan pada forum ilmiah dapat dikategorikan efektif.

\section{PENUTUP}

Hasil penelitian ini dapat disimpulkan bahwa pengaruh pendidikan lanjut terhadap kinerja guru sebesar 7,01\%. 
Pengaruh pelatihan profesi terhadap kinerja guru sebesar 38,09\%. Pengaruh kesertaan pada forum ilmiah terhadap kinerja guru sebesar 16,53\%.

Pengaruh pendidikan lanjut dan pelatihan profesi secara bersama-sama terhadap kinerja guru sebesar 38,42\%, pengaruh pendidikan lanjut dan kesertaan pada forum ilmiah secara bersama-sama terhadap kinerja guru sebesar 25,16\%, dan pengaruh pelatihan profesi dan kesertaan pada forum ilmiah secara bersama-sama terhadap kinerja guru sebesar $48,65 \%$.

Secara keseluruhan, dari ketiga program pengembangan guru, yaitu pendidikan lanjut, pelatihan profesi dan kesertaan pada forum ilmiah berpengaruh terhadap kinerja guru sebesar 61,62\%. Dengan demikian, tingkat efektivitas pengembangan guru secara keseluruhan, yakni pendidikan lanjut, pelatihan profesidankesertaan pada forum ilmiah dapat dikategorikan efektif.

\section{UCAPAN TERIMA KASIH}

Dalam melaksanakan penelitian ini, penulis banyak mendapat dukungan dari berbagai pihak yang telah memberikan motivasi kepada penulis. Untuk itu, pada kesempatan ini, penulis mengucapkan terima kasih kepada: Prof. Dr. H. Nanang Fattah, M.Pd. selaku Promotor yang telah menyisihkan waktu dari sela-sela kesibukannya untuk memberikan bimbingan dan arahan kepada penulis dari mulai kuliah hingga selesainya disertasi. Prof. Dr.H. Sumarto, MSIE. selaku Ko-promotor yang telah memberikan banyak dorongan dan bimbingan kepadapenulis.Prof.Dr.H.Akdon,M.Pd. selaku Anggota yang telah memberikan banyak dorongan dan bimbingan kepada penulis. Prof. Dr. Fuad Abdul Hamied, M.A. selaku Direktur Program Pascasarjana Universitas Pendidikan Indonesia yang telah memberikan pembinaan dan pengarahan kepada penulis. Drs. Sofwan Abdul Bari, M.Pd. sebagai Koordinator Pengawas SMK sekaligus selaku Kepala SMK Korpri Majalengka yang telah mengoKordinasikan lancarnya pengumpulan data, Drs. H. Dede Suparman, M.Pd. selaku Kepala SMKN I Kadipaten yang telah memberi kesempatan kepada penulis untuk melaksanakan penelitian, dan Drs. Wahab, M.Pd. sebagai Kepala SMK Tri Daya Budi Majalengka yang telah memberi kesempatan kepada penulis untuk melaksanakan penelitian.

\section{DAFTAR PUSTAKA}

Bernardin, H. John \& Russel, Joyce E.A. 1993. Human Resource Management. Singapore: MacGraw Hill Inc.

Cascio, Wayne F. 1993. Managing Human Resources, Productivity, Quality of Work Life, Profits. Fourth Ed. New York: Mac Graw Hill.

Castetter, William B. 1996. The Human Resource Funtion in Educational Administration.Sixth Edition. New Jersey-Columbus, Ohio: Prentice Hall.

Dharma, Surya. 2009. Manajemen Kinerja. Yogyakarta: Pustaka Pelajar.

Drucker, Peter F. 1997.Managing a time of Great Change. (Terjemahan). Jakarta:PT.AlexMedia Komputindo. 
Engkoswara. 2006. Modul: Seminar Pendidikan. ISPI. Sumedang.

Fattah, Nanang. 2008. Landasan Manajemen Pendidikan. Bandung: Remaja Rosdakarya.

Flippo, Edwin B. 1984. Manajemen Personalia Jilid I. Jakarta: Penerbit Erlangga.

H. Yamin, Martinis. 2006. Sertifikasi Profesi Keguruan di Indonesia. Jakarta: Gaung Persada Press.

Hasibuan, Malayu SP. 2009. Manajemen Sumber Daya Manusia. Jakarta: Bumi Aksara.

Hoy, WayneK. dan Miskel,Cecil G. 2001. Educational Administration: Theory, Research, and Practice. Singapore: McGraw-Hll ook Co.

Joni, Raka T. 2008. Resureksi Pendidikan Profesional Guru, Malang: LP3UM - Cakrawala Indonesia.

Laird, Dugan. 1985. Training and Development. London: Penguin.

Mariani dan Shinta, Doriza. 2009. "Strategi Mencapai Skor Penilaian Portofolio Minimal 850 bagi Guru SMK". Jurnal Pendidikan dan Kebudayaan, Volume 15, Edisi Khusus II, Jakarta: Badan Penelitian dan Pengembangan, Depdiknas.

McNergney, Robert F. dan Carrier, Carol A. 1981. Teacher Development, New York: Macmillan Publishing Co., Inc.
Sastrohadiwiryo, B. Siswanto. 2002. Manajemen Tenaga Kerja Indonesia. Jakarta: PT. Bumi Aksara.

Singarimbun, Masri \& Sofian, Effendi 1989. Metode Penelitian Survai. Jakarta: LP3ES.

Sugiyono. 2010. Metode Penelitian Kuantitatif, Kualitatif dan $R \mathcal{E} D$. Bandung: Alfabeta.

Suhendro, Haryono. 2007. Problematika Guru SMK. http://duniaguru.com, Diakses 2009.

Sukmadinata, Nana Syaodih. 2003. Landasan Psikologi Proses Pendidikan. Bandung: PT Remaja Rosdakarya.

Supranto, J. 2004. Peroposal Penelitian dengan Contoh. Jakarta: UI Press.

Supriadi, Dedi. 2001. Reformasi Pendidikan dalam Konteks Otonomi Daerah. Jogjakarta: Adi Cita Karya Nusa.

Sutermeister, Robert A. 1976. People and Productivity. New York: McGrawHill Book Company.

Tjiptono, Fandy dan Anastasia Diana. 2003. Total Quality Management. Yogyakarta : Andi Offset. 